\title{
Acrylamide in processed food
}

\section{Anita Laghulkar and Hanuman Bobade}

See end of the Paper for

Correspondence to :

\section{Anita Laghulkar}

Department of Agricultural Engineering, Maharashtra Institute of Technology, Aurangabad (M.S.) India Email : laghulkaranita@gmail. com authors' affiliation
- Abstract : Acrylamide (2-propanamide) is colorless, non-volatile crystalline solid, soluble in water formed in food products during processing; specifically high temperature long time processing like baking, frying, etc. results in production of incremental amount of acrylamide.Acrylamide has been reported to increasethe incidence of cancer in rats at doses of 1$2 \mathrm{mg} / \mathrm{kg}$ bodyweight per day. International Agency for Research on Cancer(IARC 1994) classified acrylamide as "potentially carcinogenic substance to humans". Foods processed and cooked at high temperatures contain high level of acrylamide. Acrylamide content in French fries and breads ranges from 59-5200 and 10-3200 $\mu \mathrm{g} / \mathrm{kg}$, respectively. According to WHO (2005), the maximum permissible level of acrylamide is $21-140 \mu \mathrm{g} / 70 \mathrm{~kg}$ body weight for general population. Formation of acrylamide during processing of foods depend on food composition, temperature, time of processing\& high carbohydrate, free asparagine, reducing sugars, $\mathrm{pH}$ and water content. Asparagine is the free amino acid present in potato in high level (about $90 \mathrm{mg} / 100 \mathrm{~g}$ ), needs free sugars to form acrylamide. However, many studies have revealed that the acrylamide formation in food products can be reduced by giving some pre-treatments like blanching, soaking, addition of cations and Lasparaginase enzyme to the foods. The objective of this review is to discuss the formation, mechanism and toxicological studies, ways to minimize acrylamide in heat-treated starch-rich foods.

- Key words : Acrylamide and toxicity, Maillard reaction, High temperature food processing, Pretreatments

- How to cite this paper : Laghulkar, Anita and Bobade, Hanuman (2018). Acrylamide in processed food . Internat. J. Agric. Engg., 11(Sp. Issue) : 110-115, DOI: 10.15740/HAS/IJAE/11.Sp. Issue/110115. 